\title{
Involvement of Pallidotegmental Neurons in Methamphetamine- and MK-80I-Induced Impairment of Prepulse Inhibition of the Acoustic Startle Reflex in Mice: Reversal by $\mathrm{GABA}_{B}$ Receptor Agonist Baclofen
}

\author{
Sawako Arai ${ }^{1,7}$, Kazuhiro Takuma ${ }^{1,7}$, Hiroyuki Mizoguchi', ${ }^{1,2}$ Daisuke Ibi', Taku Nagai ${ }^{3}, K^{\prime}$ jeni Takahashi', \\ Hiroyuki Kamei ${ }^{4}$, Toshitaka Nabeshima ${ }^{5}$ and Kiyofumi Yamada*,1,3,6 \\ 'Laboratory of Neuropsychopharmacology, Division of Life Sciences, Graduate School of Natural Science and Technology, Kanazawa University, \\ Kanazawa, Japan; ${ }^{2}$ Futuristic Environmental Simulation Center, Research Institute of Environmental Medicine, Nagoya University, Nagoya, Japan; \\ ${ }^{3}$ Department of Neuropsychopharmacology and Hospital Pharmacy, Nagoya University Graduate School of Medicine, Nagoya, Japan; \\ ${ }^{4}$ Laboratory of Clinical Pharmacy Practice and Health Care Management, Meijo University, Nagoya, Japan; ${ }^{5}$ Department of Chemical \\ Pharmacology, Graduate School of Pharmaceutical Sciences, Meijo University, Nagoya, Japan; ${ }^{6}$ CREST, JST, Nagoya, Japan
}

\begin{abstract}
We have previously demonstrated that pallidotegmental GABAergic neurons play a crucial role in prepulse inhibition (PPI) of the startle reflex in mice through the activation of $\mathrm{GABA}_{\mathrm{B}}$ receptors in pedunculopontine tegmental neurons. In this study, we investigated whether PPI disruption induced by methamphetamine (METH) or MK-80I is associated with the dysfunction of pallidotegmental neurons. Furthermore, we examined the effects of baclofen, a GABA ${ }_{B}$ receptor agonist, on METH- and MK-80I-induced PPI impairment. Acute treatment with METH (3 mg/kg, subcutaneouly (s.c.)) and MK-80I (>0.3 mg/kg, s.c.) significantly disrupted PPI, accompanied by the suppression of c-Fos expression in lateral globus pallidus induced by PPI. Furthermore, acute treatment with METH and MK-80I stimulated c-Fos expression in the caudal pontine reticular nucleus (PnC) in mice subjected to the PPT test, although PPI alone had no effect on c-Fos expression. Repeated treatment with I mg/kg METH for 7 days, which did not affect PPI acutely, showed similar effects on PPI and c-Fos expression to acute treatment with METH $(3 \mathrm{mg} / \mathrm{kg})$. Baclofen dose-dependently ameliorated PPI impairment induced by acute treatment with METH (3 mg/kg) and MK-80I (I mg/ $/ \mathrm{kg})$, and decreased METH- and MK-80I-stimulated c-Fos expression in PnC to the basal level. These results suggest that dysfunction of pallidotegmental neurons is involved in PPI disruption caused by METH and MK801 in mice. $G_{A B A}$ receptor may constitute a putative target in treating neuropsychiatric disorders with sensorimotor gating deficits, such as schizophrenia and METH psychosis.

Neuropsychopharmacology (2008) 33, 3164-3175; doi:I0.1038/npp.2008.4I; published online 19 March 2008
\end{abstract}

Keywords: prepulse inhibition; pallidotegmental neurons; methamphetamine; MK-80 I; baclofen; schizophrenia

\section{INTRODUCTION}

Prepulse inhibition (PPI) of the startle reflex is commonly viewed as an operational measure of a process called 'sensorimotor gating,' by which excess or trivial stimuli are screened or 'gated out' of awareness (Hoffman and Ison, 1980; Braff and Geyer, 1990). PPI is the reduction of the startle response, which occurs when a weak sensory

* Correspondence: Dr K Yamada, Department of Neuropsychopharmacology and Hospital Pharmacy, Nagoya University Graduate School of Medicine, 65 Tsuruma-cho, Showa-ku, Nagoya 466-8560, Japan,

Tel: +8I 52744 2674, Fax: +8I 52744 2682,

E-mail: kyamada@med.nagoya-u.ac.jp

${ }^{7}$ These authors contributed equally to this work.

Received 22 October 2007; revised 31 January 2008; accepted 18 February 2008 stimulus (prepulse) is presented several hundred milliseconds before a sudden intense stimulus (pulse) (Ison and Hammond, 1971; Swerdlow et al, 2001; Fendt et al, 2001; Yeomans et al, 2006).

Like the startle reflex itself, PPI is also a cross-species phenomenon. Deficits in PPI are observed in patients suffering from certain neuropsychiatric disorders such as schizophrenia. (Braff et al, 1978; Castellanos et al, 1996). Deficits of PPI in schizophrenia can be mimicked in rodents by treatment with psychostimulants such as methamphetamine (METH) (Dai et al, 2004) and non-competitive $\mathrm{N}$-methyl-D-aspartate (NMDA) receptor antagonists such as MK-801 and phencyclidine (Curzon and Decker, 1998).

In a previous study, we investigated the neuronal circuits underlying the control of PPI of the acoustic startle reflex in mice by quantifying changes in the expression of c-Fos 
protein in various areas of the brain in mice exposed to either background noise, pulses without prepulses, pulses with prepulses, or prepulses without pulses. c-Fos immunohistochemistry revealed that the lateral globus pallidus (LGP) was activated by prepulses whereas activation of the caudal pontine reticular nucleus $(\mathrm{PnC})$ evoked by startle pulses was inhibited by prepulses. Double-immunostaining revealed that c-Fos-positive cells in LGP following prepulse trials were GABAergic neurons. Furthermore, it was demonstrated that fluoro-gold infusion into $\mathrm{PnC}$ and the pedunculopontine tegmental nucleus (PPTg) retrogradely labeled neurons in PPTg and LGP, respectively. Inactivation of LGP by lidocaine resulted in impairment of PPI of the startle reflex. Microinjection with phaclofen, a $\mathrm{GABA}_{\mathrm{B}}$ receptor antagonist, into PPTg significantly impaired PPI, whereas picrotoxin, a $\mathrm{GABA}_{\mathrm{A}}$ receptor antagonist, had no effect. Based on these findings, we have proposed the hypothesis that neural circuits containing pallidotegmental GABAergic neurons play a crucial role in PPI of the acoustic startle reflex via $\mathrm{GABA}_{\mathrm{B}}$ receptors in mice (Takahashi et al, 2007).

GABA is the most important inhibitory neurotransmitter in the brain, and deficits of the GABAergic system, including the reduced number of parvalbumin-containing GABAergic interneurons, have been documented in the prefrontal cortex of patients with schizophrenia (Benes and Berretta, 2001; Lewis et al, 2001). Previous studies have indicated that the reduction of GABAergic interneurons in schizophrenia is paralleled by increased $\mathrm{GABA}_{\mathrm{A}}$ receptor binding in the prefrontal cortex (Benes et al, 1996). In contrast, a marked reduction of $\mathrm{GABA}_{\mathrm{B}}$ receptors was reported in the hippocampus and prefrontal cortex (Mizukami et al, 2000; Ishikawa et al, 2005). Although the role of $\mathrm{GABA}_{\mathrm{B}}$ receptors in schizophrenia and related disorders is still poorly understood, recent pharmacologic studies have demonstrated that baclofen, a $\mathrm{GABA}_{\mathrm{B}}$ receptor agonist, prevents PPI deficits in rodents (Bortolato et al, 2004, 2007).

In this study, we investigated whether PPI disruption caused by METH and MK-801 is associated with the dysfunction of pallidotegmental neurons in mice, by quantifying changes in c-Fos expression in LGP and PnC after the PPI test. Furthermore, we examined the effect of baclofen on METH- and MK-801-induced disruption of PPI of the startle reflex in mice.

\section{MATERIALS AND METHODS}

\section{Animals}

Male ICR mice (Nihon SLC Co., Shizuoka, Japan), 7 weeks old at the beginning of the experiments, were used. The animals were housed in plastic cages (5-6 mice per cage), and kept in a regulated environment $\left(23 \pm 1^{\circ} \mathrm{C}, 50 \pm 5 \%\right.$ humidity), with a $12 \mathrm{~h}$ light-dark cycle (lights on at $0900 \mathrm{~h}$ ). Food (Labo MR Stock, Nihon Nosan Kogyou Inc., Kanagawa, Japan) and tap water were available ad libitum. The animals were used for the experiments after 7 days of acclimatization to laboratory conditions. All behavioral experiments were carried out between 1000 and 1700 hours.

All animal care and use were in accordance with the National Institutes Health Guide for the Care and Use of
Laboratory Animals and were approved by the Institutional Animal Care and Use Committee of Kanazawa University.

\section{Drugs}

METH hydrochloride (Dainippon Sumitomo Pharma Co. Ltd., Osaka, Japan), MK-801 (Sigma-Aldrich Co., St Louis, MO), and baclofen (Sigma-Aldrich) were dissolved in physiological saline and administered at a volume of $0.1 \mathrm{ml} / 10 \mathrm{~g}$ body weight.

For the acute treatment test, mice were given a subcutaneous (s.c) injection of saline, METH (1 or $3 \mathrm{mg}$ / $\mathrm{kg}$ ), or MK-801 (0.3 or $1 \mathrm{mg} / \mathrm{kg}), 10 \mathrm{~min}$ before the PPI test. Baclofen ( 1 or $5 \mathrm{mg} / \mathrm{kg}$, s.c.) was pretreated $15 \mathrm{~min}$ before METH and MK-801 treatments. For the repeated METH treatment test, animals were injected with $\mathrm{METH}(1 \mathrm{mg} / \mathrm{kg}$, s.c.) once a day for 7 days. The animals were subjected to the PPI test $10 \mathrm{~min}, 3,7$ or 14 days after the last administration of METH. Control animals were given saline under the same schedule as for repeated administration of METH.

\section{PPI Test}

A standard startle chamber applicable to mice and rats (San Diego Instruments, San Diego, CA) was used. The startle chamber consisted of a Plexiglas tube for mice $(105 \mathrm{~mm}$, $38 \mathrm{~mm}$ i.d., $50 \mathrm{~mm}$ o.d.), placed in a sound-attenuated text box, in which animals were individually placed. The tube was mounted on a plastic frame under which a piezoelectric accelerometer was mounted, which recorded and transduced the motion of the tube.

Animals were randomly divided into non-stimulated and PPI groups, and subjected to the behavioral test only once. Mice were placed into the chamber in the PPI test cage, and then habituated to the experimental environment for $10 \mathrm{~min}$ with $65 \mathrm{~dB}$ of background white noise. Non-stimulated control mice were used without being subjected to PPI trials. The PPI test has three continuous sessions: (1) five startle trials, (2) 10 startle trials, 10 no-stimulus trials, and 40 PPI trials, and (3) five startle trials. The intertrial interval was between 10 and $20 \mathrm{~s}$, and the total duration of three sessions was $17 \mathrm{~min}$. The startle trial consisted of a single $120 \mathrm{~dB}$ white noise burst lasting $40 \mathrm{~ms}$. The PPI trials consisted of a prepulse $(20 \mathrm{~ms}$ burst of white noise with intensities of $69,73,77$, or $81 \mathrm{~dB}$ ) followed, $100 \mathrm{~ms}$ later, by the startle stimulus $(120 \mathrm{~dB}, 40 \mathrm{~ms}$ white noise). Each of the four prepulse trials $(69,73,77$, or $81 \mathrm{~dB})$ was presented 10 times. During the no-stimulus trial, no stimulus was presented but the movement of the animal was scored. Sixty different trials were presented pseudo-randomly, ensuring that each trial was presented 10 times and that no two consecutive trials were identical. The resulting movement of the animal in the startle chamber was measured during $100 \mathrm{~ms}$ after startle stimulus onset (sampling frequency $1 \mathrm{kHz}$ ), rectified, amplified, and fed into a computer, which calculated the maximal response over the 100-ms period. Basal startle amplitude was determined as the mean amplitude of the 10-startle trials. PPI was calculated according to the formula: $100 \times[1-(\mathrm{PPx} / \mathrm{P} 120)] \%$, in which $\mathrm{PPx}$ was the mean of the 10 PPI trials (PP69, PP73, PP75, or PP80) and P120 was 
the basal startle amplitude (Ellenbroek et al, 2002; Takahashi et al, 2007).

\section{Fos Immunohistochemistry}

c-Fos immunostaining was performed as described previously (Takahashi et al, 2007). As Fos expression was shown to occur from 1 to $4 \mathrm{~h}$ after a single short stimulation (Herdegen and Leah, 1998), animals were deeply anesthetized with sodium pentobarbital $(50 \mathrm{mg} / \mathrm{kg}) 2 \mathrm{~h}$ after the PPI test. Alternatively, mice were treated with saline, METH (3 mg/kg, s.c.), or MK-801 (1 mg/kg, s.c.) and killed $2.5 \mathrm{~h}$ after treatment without the PPI test. The animals were transcardially perfused with ice-cold phosphate-buffered saline (PBS), followed by $4 \%$ paraformaldehyde in PBS. The brains were removed, post-fixed in the same fixative for $2 \mathrm{~h}$ and then cryoprotected in $30 \%$ sucrose in PBS. Frozen serial coronal sections $(20 \mu \mathrm{m})$ of the entire brain were made and incubated with $10 \%$ goat serum and $0.1 \%$ Triton $\mathrm{X}-100$ in $0.1 \mathrm{M}$ phosphate buffer, and then incubated with rabbit anti-c-Fos antibody (1:200; sc-253, Santa Cruz Biotechnology, CA) for $24 \mathrm{~h}$ at $4^{\circ} \mathrm{C}$. They were washed with phosphate buffer and incubated with biotinylated goat anti-rabbit antibody (1:200; BA-1000, Vector Laboratories, Burlingame) at room temperature for $1 \mathrm{~h}$. The sections were washed and processed with avidin-biotinylated horseradish peroxidase complex (Vector ABC kit, Vector Laboratories), and the reaction was visualized using diaminobenzidine.

\section{Quantitative Analysis of c-Fos Immunohistochemistry}

To quantify the number of Fos-positive cells in the brain, we used a fluorescence microscope with a cooled CDD digital camera system (Axio Imager A1/AxioCam MRc5; Carl Zeiss, Jene, Germany) to scan the sections, and calculated the cell numbers from the digitized images using image-analyzing software Win ROOF (ver. 5.6, Mitani Co., Fukui, Japan). We selected three different sections from each animal, which showed typical and average responses in the PPI test, and defined the region of interest (ROI), $500 \times 500$ pixels $(168 \times 168 \mu \mathrm{m})$, using the software in both right and left hemispheres of the sections according to a mouse brain atlas (Franklin and Paxinos, 1997). To avoid doublecounting errors, we chose a counting protocol in the software, which does not calculate cell numbers on the border of ROI. c-Fos-positive cells were counted three times with differential ROI in the same section. The average of the resulting nine determinations of the c-Fos-positive cell numbers was used for statistical analysis (Takahashi et al, 2007). c-Fos-positive cells were counted by an individual blind to the treatment conditions. In the acute drug treatment test, selected areas were as follows: LGP, PnC, medial prefrontal cortex (mPFC), somatosensory cortex (SC), core and shell of the nucleus accumbens (NAc). In the repeated METH treatment test, only LGP and PnC were selected.

\section{Statistical Analysis}

Results are expressed as the mean \pm SE. The significance of differences was determined by one-way analysis of variance (ANOVA) in experiments counting c-Fos-positive cells and by repeated measures ANOVA in PPI response measurement, followed by the post hoc Bonnferroni/Dunn test. Unpaired $t$-test was used for two-group comparisons. $p$-values less than 0.05 were regarded as statistically significant.

\section{RESULTS}

\section{Effect of Acute Treatment with METH and MK-801 on PPI of the Acoustic Startle Reflex in Mice}

Figure 1 shows the effect of acute METH (1 and $3 \mathrm{mg} / \mathrm{kg}$, s. c.) and $\mathrm{MK}-801(0.3$ and $1 \mathrm{mg} / \mathrm{kg}$, s.c.) treatment on PPI in mice. For the effect of METH, repeated measures of ANOVA revealed significant effects of METH treatment $(\mathrm{F}(2,31)=$ $8.711, p<0.01)$ and prepulse intensity $(\mathrm{F}(3,93)=11.023$, $p<0.001)$, but not their interaction $(\mathrm{F}(6,93)=0.908$, $p>0.05)$. METH at a dose of $3 \mathrm{mg} / \mathrm{kg}$ significantly reduced PPI compared with the saline-treated control group $(p<0.001)$ (Figure 1a). For the effect of MK-801, there were significant effects of MK-801 treatment $(\mathrm{F}(2,29)=8.337$, $p<0.01)$ and prepulse intensity $(\mathrm{F}(3,87)=14.646$, $p<0.001)$, but not their interaction $(\mathrm{F}(6,87)=0.224$, $p>0.05)$. MK-801 dose-dependently reduced PPI compared with the saline-treated control group $(p<0.01)$ (Figure 1c). METH had no effect on the startle amplitude (Figure 1b), whereas $\mathrm{MK}-801$ at $0.3 \mathrm{mg} / \mathrm{kg}$ significantly increased the startle amplitude $(\mathrm{F}(2,29)=7.418, p<0.01)$ (Figure 1d).

\section{PPI-Associated Changes in c-Fos Expression in the LGP and PnC of Mice Treated with Acute METH and MK-801}

To detect the effects of drug treatment on pallidotegmental neural activation after the PPI test, we examined c-Fos expression immunohistochemically in the LGP and PnC of mice treated with saline, METH (3 mg/kg, s.c.), or MK-801 $(1 \mathrm{mg} / \mathrm{kg}$, s.c.). Representative photomicrographs of c-Fos staining in the LGP and PnC after the PPI test are shown in Figures 2 and 3, respectively. Quantitative analysis of c-Fos staining indicated a significant difference in the number of c-Fos-positive cells in the LGP $(\mathrm{F}(3,14)=60.936, p<0.001)$ (Figure $4 \mathrm{a}$ ). There was a significant increase in the number of c-Fos-positive cells in saline-treated control mice subjected to the PPI test $(n=4)$ compared with nonstimulated mice $(n=5)(p<0.001)$. The number of c-Fospositive cells in the LGP of mice treated with METH $(n=4)$ or MK-801 $(n=5)$ was significantly less than that in salinetreated control mice subjected to the PPI test $(p<0.001)$.

A significant change in c-Fos expression was also observed in the $\operatorname{PnC} \quad(\mathrm{F}(3,14)=14.43, \quad p<0.001)$ (Figure $4 \mathrm{~b})$. There was no difference in the number of $c$ Fos-positive cells between non-stimulated mice $(n=4)$ and saline-treated control mice subjected to the PPI test $(n=4)$. The number of c-Fos-positive cells in the $\mathrm{PnC}$ of mice treated with METH $(n=4)$ or MK-801 $(n=4)$ was significantly increased compared with that in saline-treated control mice $(p<0.001)$.

Furthermore, we analyzed the changes of c-Fos expression in the mPFC, SC, NAc shell, and NAc core of mice treated with saline $(n=4), \operatorname{METH}(3 \mathrm{mg} / \mathrm{kg}$, s.c., $n=4)$, or MK-801 ( $1 \mathrm{mg} / \mathrm{kg}$, s.c., $n=4)$ after the PPI test (Figure 5). Significant differences in c-Fos expression were observed in 
a
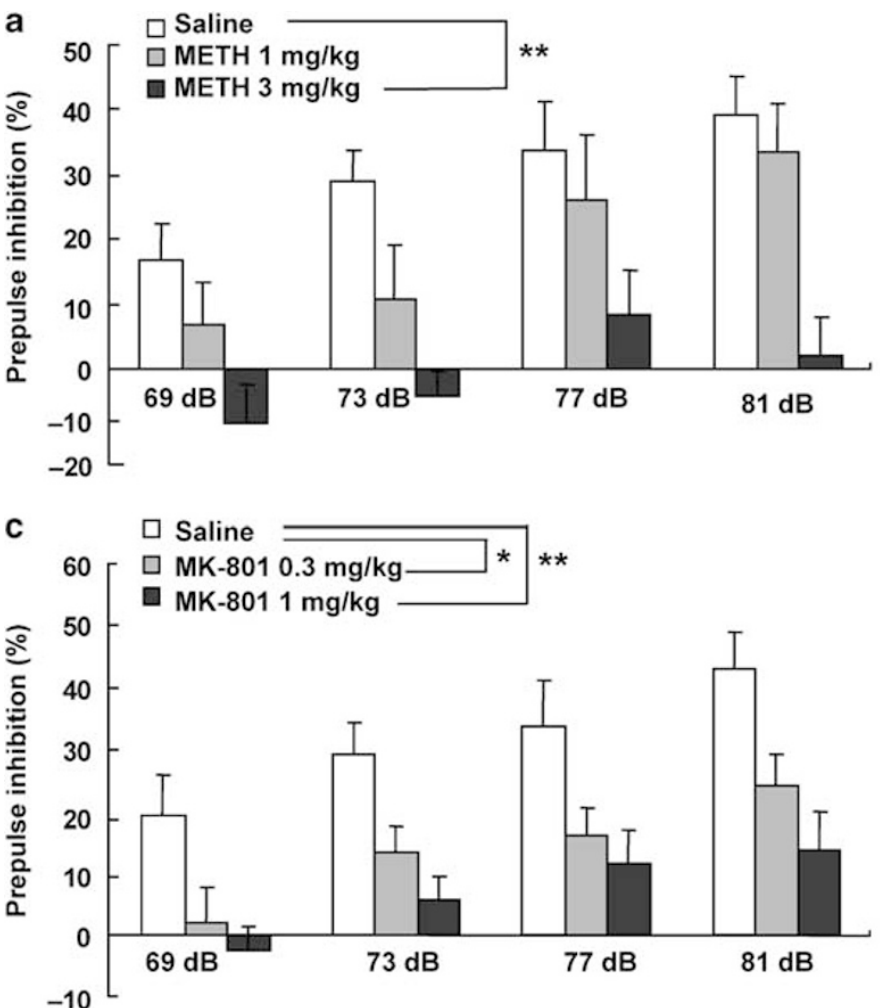

b

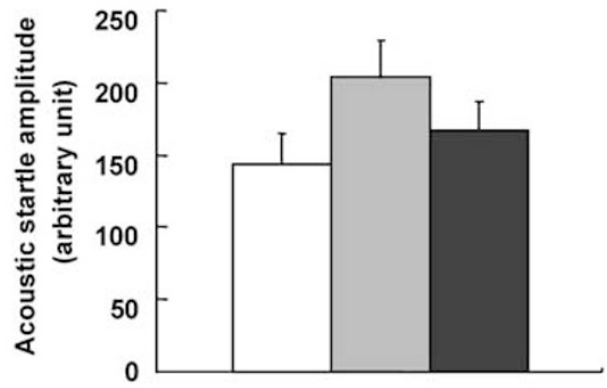

d

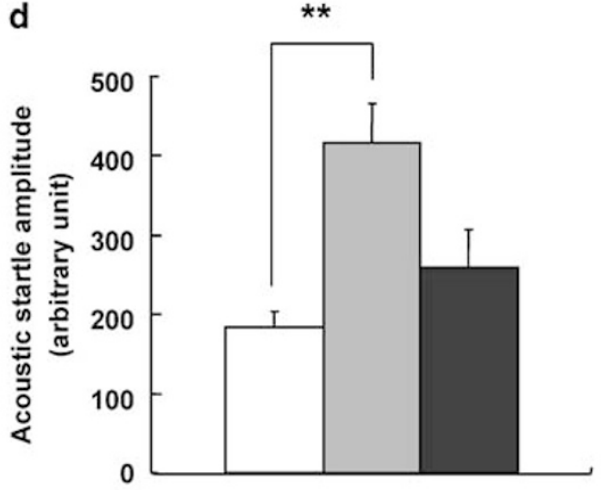

Figure I Effects of acute METH and MK-80 I treatment on PPI in mice. Mice were treated with saline, METH (I and 3 mg/kg, s.c.) (a, b), or MK-80 I (0.3 and I mg/kg, s.c) (c, d) 10 min before the PPI test. (a, c) PPI (\%) at four different prepulse intensities (69, 73, 77, and 8I dB). (b, d) Acoustic startle amplitude as measured in trials without a prepulse. Values indicate the mean $\pm \mathrm{SE}(\mathrm{a}$, b: saline, $n=1 \mathrm{I}, \mathrm{METH} I \mathrm{mg} / \mathrm{kg}, n=1 \mathrm{I}, \mathrm{METH} 3 \mathrm{mg} / \mathrm{kg}, \mathrm{n}=12 ; \mathrm{c}, \mathrm{d}$ : saline, $n=9, M K-8010.3 \mathrm{mg} / \mathrm{kg}, n=12, M K-80 \mathrm{I} \mid \mathrm{mg} / \mathrm{kg}, n=1 \mathrm{I}$ ). ${ }^{*} p<0.01$, ${ }^{*} * p<0.00 \mathrm{I}$ vs the saline-treated control group (Bonnferroni/Dunn test).

the $\operatorname{mPFC}(\mathrm{F}(3,12)=7.616, p<0.01)$, NAc shell $(\mathrm{F}(3,12)=$ $11.047, p<0.001)$, and NAc core $(\mathrm{F}(3,12)=21.033$, $p<0.001)$, whereas there were no significant differences in the SC. There was no difference in the number of c-Fospositive cells in the mPFC, SC, NAc shell, and NAc core between non-stimulated mice and saline-treated control mice subjected to the PPI test. The numbers of $c$-Fospositive cells in the mPFC $(p<0.01)$ and NAc core $(p<0.01)$ of the METH-treated group were significantly increased compared with those in the saline-treated control group. In contrast, a significant decrease in the number of c-Fospositive cells was observed in the NAc shell of the MK-801treated group compared with the saline-treated control group $(p<0.01)$. Thus, the effects of METH and MK-801 on the behavioral responses of mice in the PPI test paralleled with the neuronal activity in the LGP, raising the possibility that LGP may be critical for the PPI disruption induced by METH and MK-801.

As a control experiment, we measured the effects of METH (3 mg/kg, s.c.) and MK-801 (1 mg/kg, s.c.) on c-Fos expression in various brain areas of mice that were not subjected to the PPI test (Supplementary Figure S1). Acute METH treatment had no effect on c-Fos expression in the LGP and PnC, but significantly increased the expression in the mPFC, SC, NAc shell, and NAc core $(p<0.01)$. Similarly, acute $\mathrm{MK}-801$ treatment did not affect c-Fos expression in the LGP and PnC, while it increased the number of Fospositive cells in the MPFC and SC $(p<0.001)$. From this control experiment, it is obvious that the effects of METH and MK-801 on c-Fos expression in mice that were subjected to the PPI test are markedly different from those found in mice that were not subjected to the test.

\section{Effect of Repeated Treatment with METH on PPI of the Acoustic Startle Reflex in Mice}

Figure 6 shows the effect of single and repeated treatment with METH ( $1 \mathrm{mg} / \mathrm{kg}$, s.c.) on PPI in mice. Repeated measures of ANOVA revealed significant effects of repeated METH treatment $(\mathrm{F}(2,18)=9.152, p<0.01)$ and prepulse intensity $(\mathrm{F}(3,54)=18.311, p<0.001)$, but not their interaction $(F(6,54)=1.804, p>0.05)$. Repeated, but not single, METH treatment induced a significant impairment of PPI of the startle reflex compared with saline treatment $(p<0.01)$ (Figure 6a). Acute and repeated METH treatment had no effect on the startle amplitude (Figure 6b).

Repeated METH-induced PPI disruption was observed after the withdrawal of METH for at least 7 days without any changes in the startle response. There were significant effects of repeated METH treatment $(\mathrm{F}(1,18)=9.101$, $p<0.01)$, prepulse intensity $(\mathrm{F}(3,54)=49.709, p<0.001)$, and their interaction $(\mathrm{F}(3,54)=3.7, p<0.05)(n=10$ in each group). However, the disruptive effect of repeated METH treatment on PPI disappeared after withdrawal for 14 days (data not shown). 


\section{Lateral globus pallidus (LGP)}
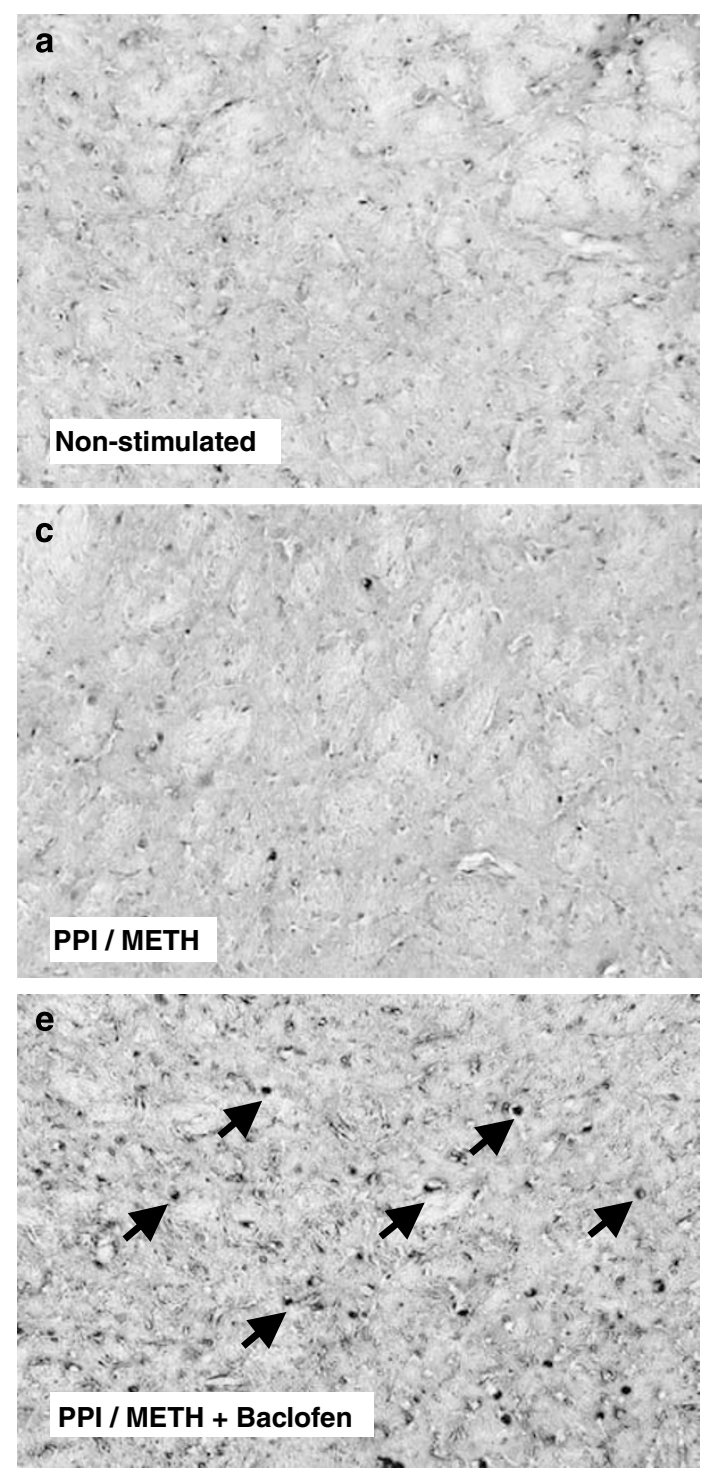
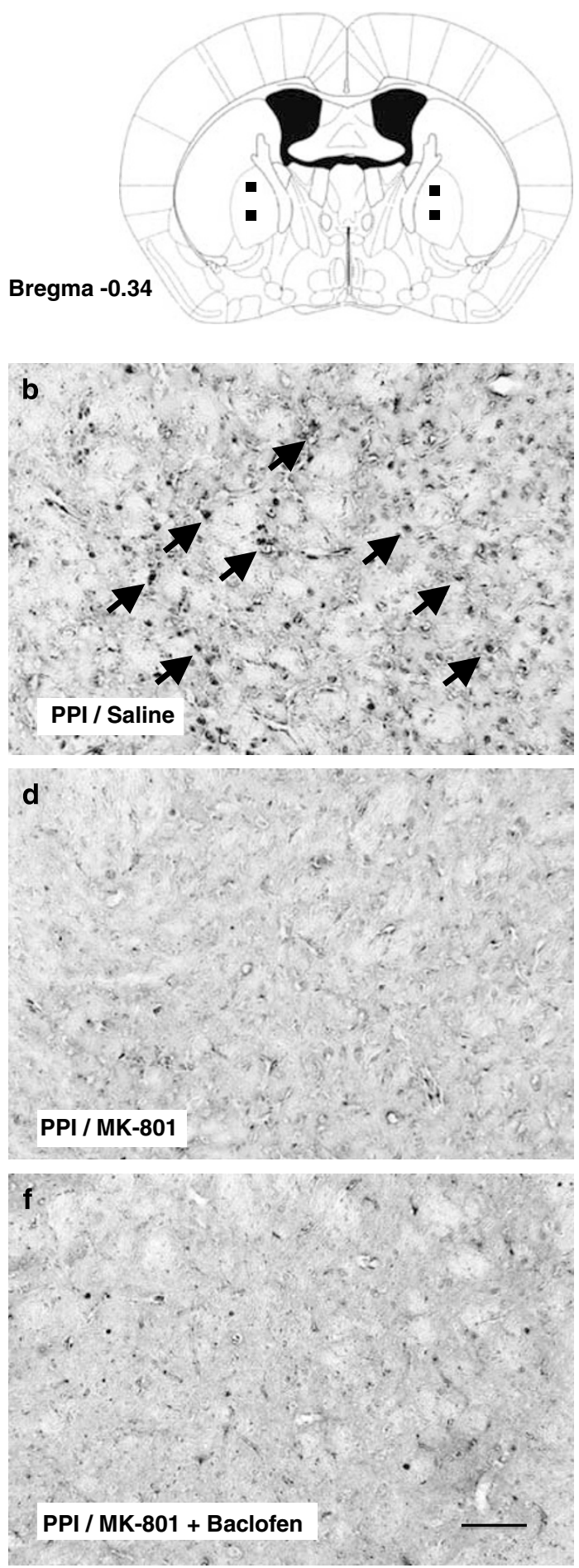

Figure 2 Representative photomicrographs of c-Fos immunostaining in LGP after the PPI test. Mice were restricted to the PPI test cage, but not subjected to the PPI test (non-stimulated group, a). Alternatively, mice were subjected to the PPI test after pretreatment with saline (b), METH (3 mg/kg, c), MK-80 I $(\mathrm{I} \mathrm{mg} / \mathrm{kg}, \mathrm{d})$, and baclofen $(5 \mathrm{mg} / \mathrm{kg})$ I 5 min before METH (e) or MK-80 I (f) treatment. Scale bar, I00 $\mu \mathrm{m}$. Arrows indicate typical c-Fos-positive cells.

\section{PPI-Associated Changes in c-Fos Expression in the LGP and PnC of Mice with Repeated METH Treatment}

To examine the effects of repeated METH treatment on pallidotegmental neural activation after the PPI test, we examined c-Fos expression immunohistochemically in the LGP and PnC of mice treated with saline, single, or repeated
METH after the PPI test (Figure 7). A significant difference in the number of c-Fos-positive cells was observed in LGP $(\mathrm{F}(3,13)=117.265, \quad p<0.001)$. There was a significant increase in c-Fos expression in saline-treated control mice subjected to the PPI test $(n=4)$ compared with nonstimulated mice $(n=5)(p<0.001)$. In contrast, the number of c-Fos-positive cells in the LGP of mice with repeated 
Caudal pontine reticular nucleus $(\mathrm{PnC})$
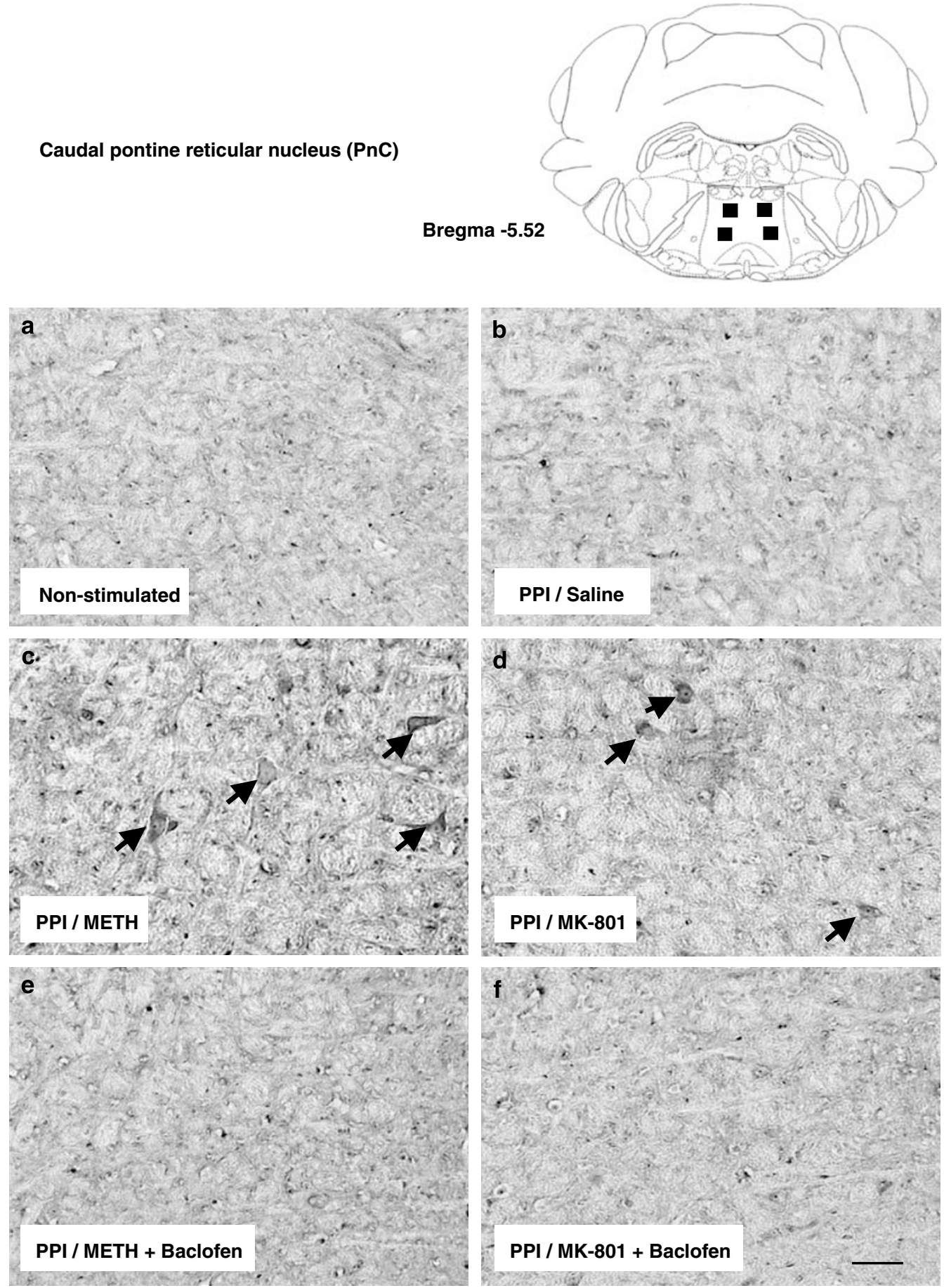

Figure 3 Representative photomicrographs of c-Fos immunostaining in PnC after the PPI test. Mice were restricted to the PPI test cage, but not subjected to the PPI test (non-stimulated group, a). Alternatively, mice were subjected to the PPI test after pretreatment with saline (b), METH (3 mg/kg, c), MK-80 $(\mathrm{I} \mathrm{mg} / \mathrm{kg}, \mathrm{d})$, and baclofen $(5 \mathrm{mg} / \mathrm{kg}) 15 \mathrm{~min}$ before METH (e) or MK-80I (f) treatment. Scale bar, I00 $\mu \mathrm{m}$. Arrows indicate typical c-Fos-positive cells.

METH treatment $(n=4)$ was significantly lower than that in saline-treated control mice $(p<0.001)$. There was a slight, but significant decrease in c-Fos expression in the acutely METH-treated group $(n=4)$ compared with the salinetreated control group.

A significant difference in c-Fos expression was also observed in $\operatorname{PnC}(F(3,16)=13.217, p<0.001)$. There was no difference in c-Fos expression between non-stimulated mice $(n=5)$ and saline-treated control mice $(n=5)$ subjected to the PPI test; however, c-Fos expression in repeated $(n=5)$, but not acute $(n=5)$, METH-treated mice was significantly increased compared with saline-treated control mice $(p<0.001)$.

Mice exhibited normal PPI after withdrawal from METH for 14 days and no changes in c-Fos expression were observed in both LGP and PnC as compared with saline-treated control mice (unpaired $t$-test, data not shown). 
a

LGP

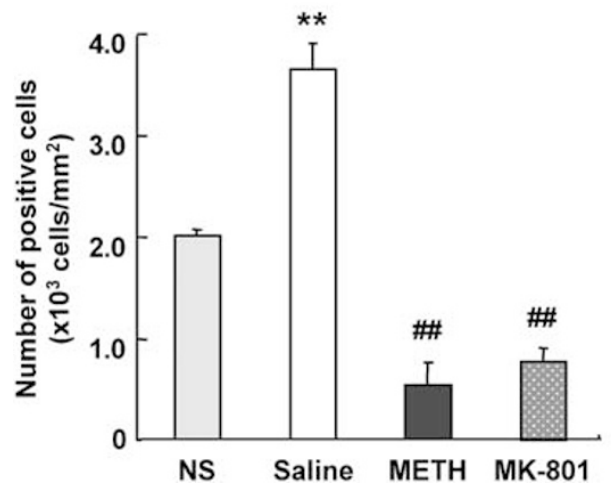

b

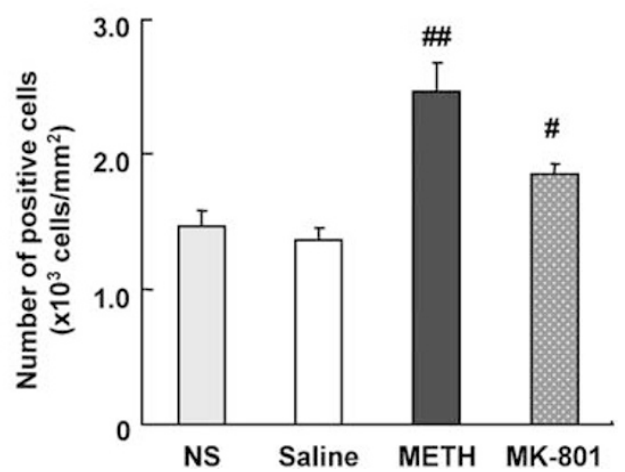

Figure 4 Effects of acute METH and MK-80I treatment on changes in c-Fos expression in LGP (a) and PnC (b) after the PPI test. Mice were restricted to the PPI test cage, but not subjected to the PPI test (non-stimulated group: NS). Alternatively, mice were subjected to the PPI test after pretreatment with saline, METH (3 mg/ $/ \mathrm{kg})$, and MK-80 I ( I mg/ $/ \mathrm{kg})$. Values indicate the mean \pm SE. ${ }^{*} * p<0.00 \mathrm{I}$ vs the non-stimulated group. ${ }^{\#} p<0.0 \mathrm{I}$, ${ }^{\# \#} p<0.00 \mathrm{I}$ vs the salinetreated control group (post hoc test).
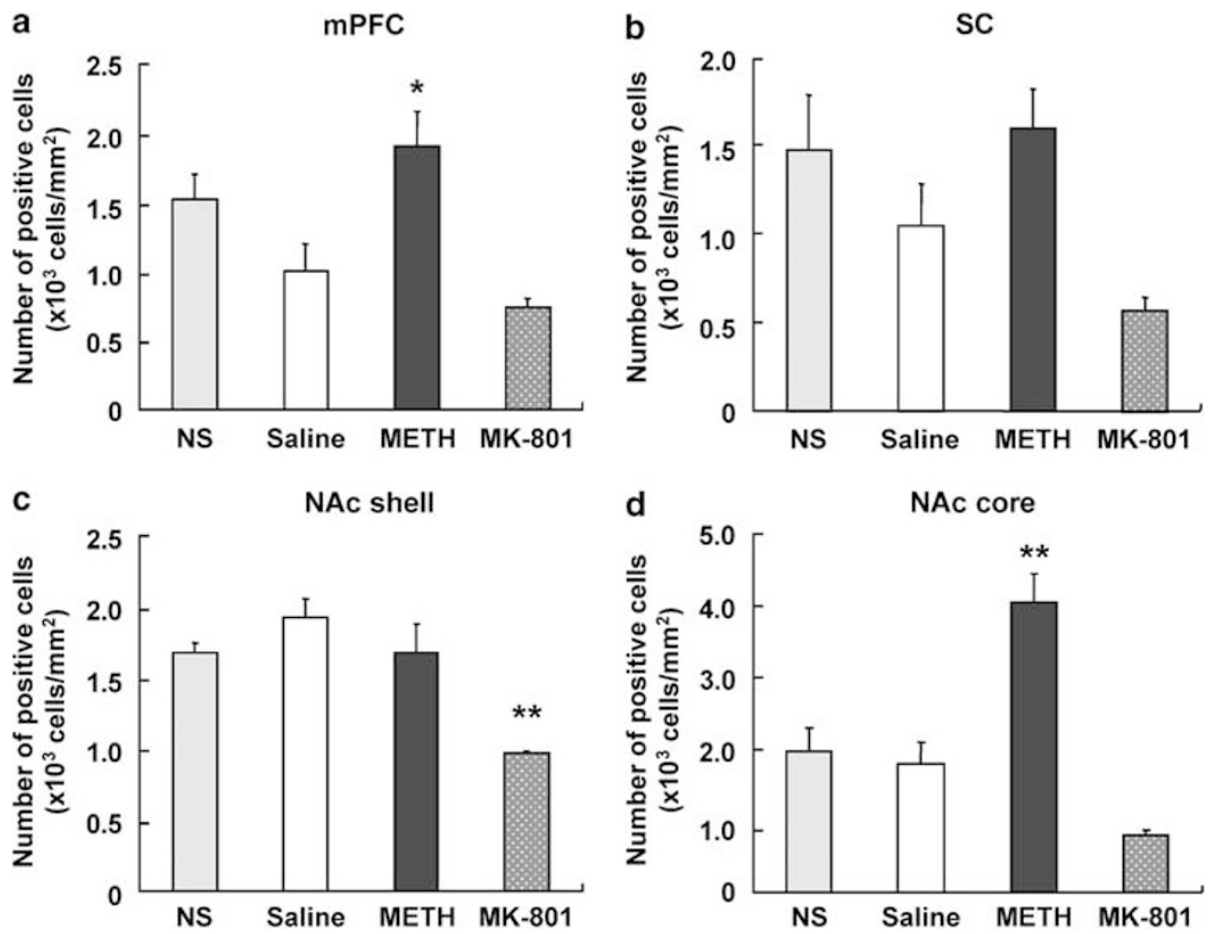

Figure 5 Effects of acute METH and MK-80I treatment on c-Fos expression in the mPFC (a), SC (b), NAc shell (c), and NAc core (d) after the PPI test. Mice were restricted to the PPI test cage, but not subjected to the PPI test (non-stimulated group: NS). Alternatively, mice were subjected to the PPI test after pretreatment with saline, METH $(3 \mathrm{mg} / \mathrm{kg})$, and MK-80 I ( I mg/ $/ \mathrm{kg})$. Values indicate the mean \pm SE (all groups, $n=4)$. * $p<0.0 \mathrm{I}, * * p<0.00 \mathrm{I}$ vs the saline-treated control group (post hoc test).

\section{Effects of Baclofen on METH- and MK-801-Induced PPI Impairment in Mice}

Baclofen ( 1 and $5 \mathrm{mg} / \mathrm{kg}$, s.c.), a $\mathrm{GABA}_{\mathrm{B}}$ receptor agonist, dose-dependently reversed the impairment of PPI induced by METH (3 mg/kg, s.c.) and MK- 801 ( $1 \mathrm{mg} / \mathrm{kg}$, s.c.) without any effects on the startle amplitude (Figure 8). For the effect of baclofen on METH-induced PPI disruption, there were significant effects of drug treatment $(\mathrm{F}(3,26)=6.73, \quad p<0.01)$ and prepulse intensity $(\mathrm{F}(3,78)=33.278, \quad p<0.001)$, but not their interaction
$(\mathrm{F}(9,78)=0.550, \quad p>0.05) . \quad$ METH significantly reduced PPI compared with the saline-treated control group $(p<0.01)$. Baclofen, at a dose of $5 \mathrm{mg} / \mathrm{kg}$, significantly ameliorated PPI impairment in the METH-treated group $(p<0.001)$ (Figure 8a). For the effect of baclofen on MK801-induced PPI disruption, there were significant effects of drug treatment $(\mathrm{F}(3,24)=4.852, p<0.01)$ and prepulse intensity $(\mathrm{F}(3,72)=49.336, p<0.001)$, but not their interaction $(F(9,72)=0.1467, p>0.05)$. MK-801 significantly reduced PPI compared with the saline-treated control group $(p<0.01)$. Baclofen at a dose of $5 \mathrm{mg} / \mathrm{kg}$ significantly 

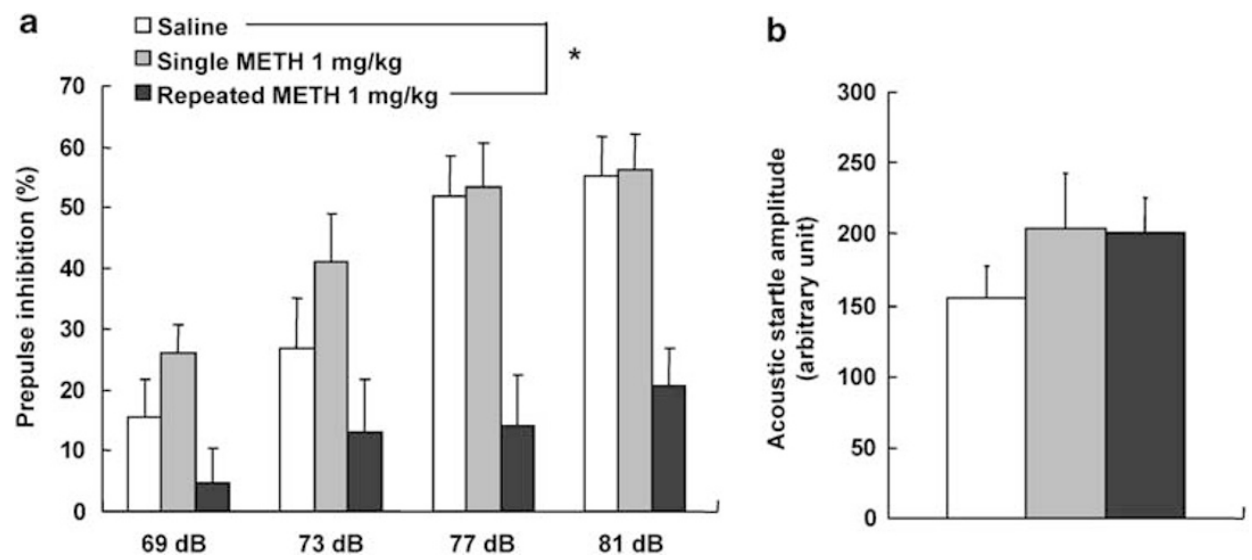

Figure 6 Effects of single and repeated METH treatment on PPI in mice. Mice were treated with METH (I mg/kg, s.c.) acutely I0 min before the PPI test. Alternatively, METH (I mg/kg) was repeatedly injected into mice for 7 days, and the animals were subjected to the PPI test 10 min after the last injection. (a) PPI (\%) at four different prepulse intensities $(69,73,77$, and $8 \mathrm{I} \mathrm{dB}$ ). (b) Acoustic startle amplitude as measured in trials without a prepulse. Values indicate the mean $\pm S E(a$, b: all groups, $n=7)$. ${ }^{2} p<0.0$ I vs the saline-treated control group (Bonnferroni/Dunn test).
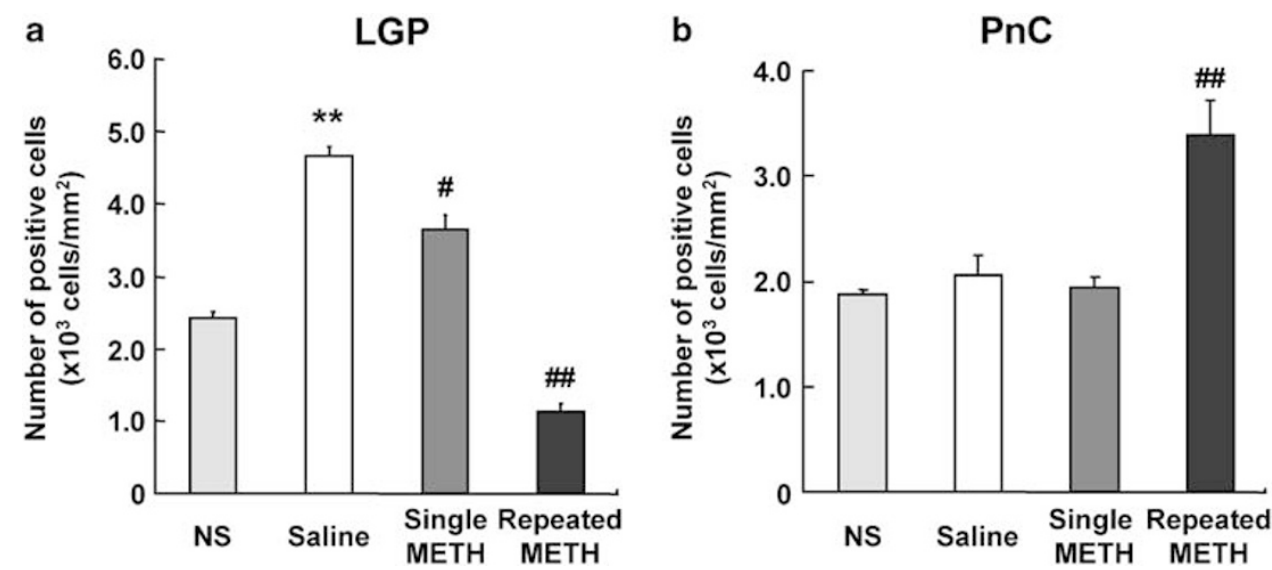

Figure 7 Effects of single and repeated METH treatment on changes in c-Fos expression in the LGP (a) and PnC (b) after the PPI test. Mice were restricted to the PPI test cage, but not subjected to the PPI test (non-stimulated group: NS). Alternatively, mice were subjected to the PPI test I0 min after pretreatment with acute saline, METH (I mg/kg, s.c.), and repeated METH treatment for 7 days. Values indicate the mean \pm SE (a: non-stimulated, $n=5$, other groups, $n=4$; b: all groups, $n=5$ ). ${ }^{*} * p<0.001$ vs the non-stimulated group. ${ }^{\#} p<0.0$ I, ${ }^{\# \#} p<0.00$ I vs the saline-treated control group (Bonnferroni/ Dunn test).

increased PPI compared with the MK-801-treated group $(p<0.01)$ (Figure 8c). Acute treatment with baclofen alone ( 1 and $5 \mathrm{mg} / \mathrm{kg}$ ) had no effect on PPI or the startle response in mice (data not shown).

Effects of Baclofen on the METH- and MK-801-Induced Changes in c-Fos Expression in the LGP and PnC of Mice Subjected to the PPI Test

To study the effects of baclofen $(5 \mathrm{mg} / \mathrm{kg}$, s.c.) on METHand MK-801-induced changes in pallidotegmental neural activation in mice that were subjected to the PPI test, we examined c-Fos expression immunohistochemically in the LGP and PnC of mice after the PPI test. Representative photomicrographs of c-Fos staining in the LGP and PnC are shown in Figures 2 and 3, respectively.

As shown in Figure 9, quantitative analysis of c-Fos staining indicated a significant difference in the number of
c-Fos-positive cells in LGP $(\mathrm{F}(4,12)=25.589, p<0.001)$. There was a significant decrease in c-Fos expression in the LGP of mice treated with METH $(3 \mathrm{mg} / \mathrm{kg}, n=3)$ or MK-801 $(1 \mathrm{mg} / \mathrm{kg}, n=3)$ compared with the saline-treated control group $(n=3) \quad(p<0.001)$. Pretreatment with baclofen significantly increased the number of $c$-Fos-positive cells in the LGP compared with the METH-treated group $(n=4)(p<0.001)$. In contrast, baclofen had no effect on MK-801-induced reduction of c-Fos expression in the LGP $(n=4)$, although it ameliorated the MK-801-induced disruption of PPI.

A significant effect of baclofen on c-Fos expression was also observed in the PnC $(\mathrm{F}(4,12)=25.008, p<0.001)$. c-Fos expression in the PnC of mice treated with METH $(n=3)$ or MK-801 $(n=3)$ was significantly increased compared with saline-treated control mice $(n=3)(p<0.001)$. Both METH $(n=4)$ - and MK-801 ( $n=5)$-induced increase in the number of c-Fos-positive cells in PnC was suppressed by pretreatment with baclofen $(p<0.001)$. 

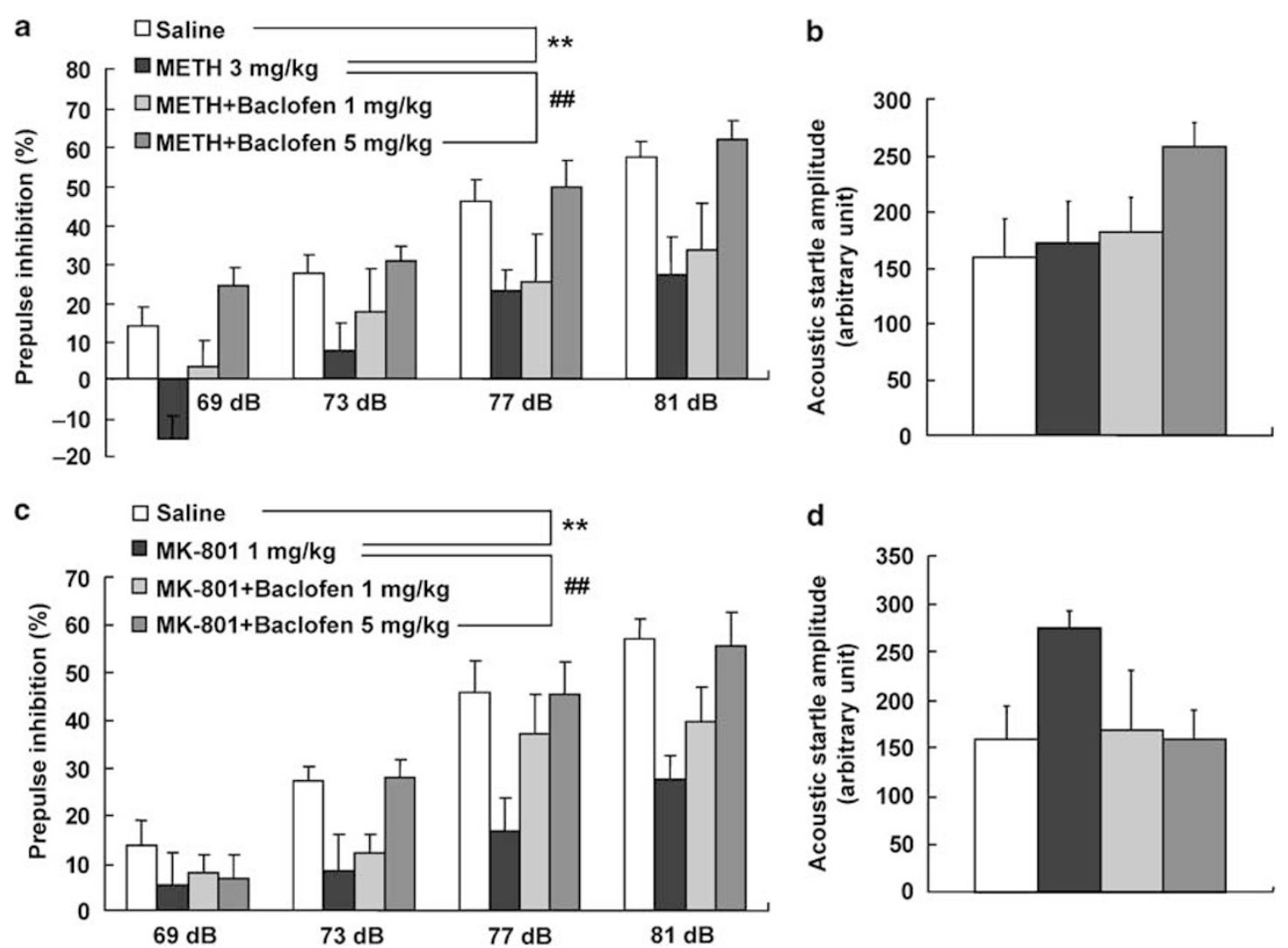

d

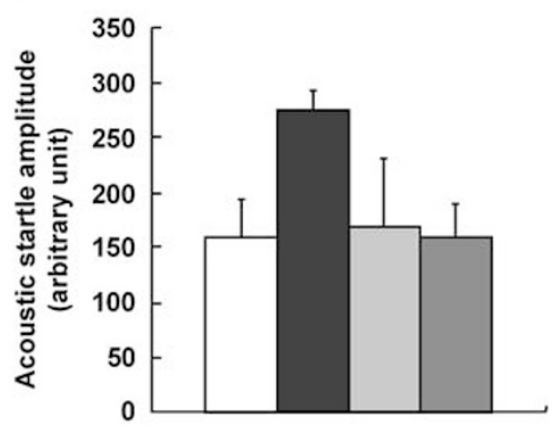

Figure 8 Effects of baclofen on acute METH- and MK-80I-induced impairment of PPI in mice. Mice were treated with baclofen (I and $5 \mathrm{mg} / \mathrm{kg}$, s.c.) $15 \mathrm{~min}$ before METH (3 mg/kg, s.c.) (a, b) or MK-80 I ( $\mathrm{mg} / \mathrm{kg}$, s.c.) (c, d) treatment. (a, c) PPI (\%) at four different prepulse intensities (69, 73, 77, and 8I dB). $(b, d)$ Acoustic startle amplitude as measured in trials without a prepulse. Values indicate the mean \pm SE $(a, b:$ saline, $n=7, M E T H: n=7, M E T H$ with baclofen I mg/kg: $n=8$, METH with baclofen $5 \mathrm{mg} / \mathrm{kg}: n=9$; c, d: saline: $n=7$, MK-80 I: $n=6$, MK-80 I with baclofen I mg/ $/ \mathrm{kg}: n=8$, MK-80 I with baclofen $5 \mathrm{mg} / \mathrm{kg}: \mathrm{n}=7)$. ${ }^{*} \mathrm{*} p<0.00$ I vs the saline-treated control group. ${ }^{\# \#} p<0.0 \mathrm{I}$ vs the METH- or MK-80 I-treated group (Bonnferroni/Dunn test).

a

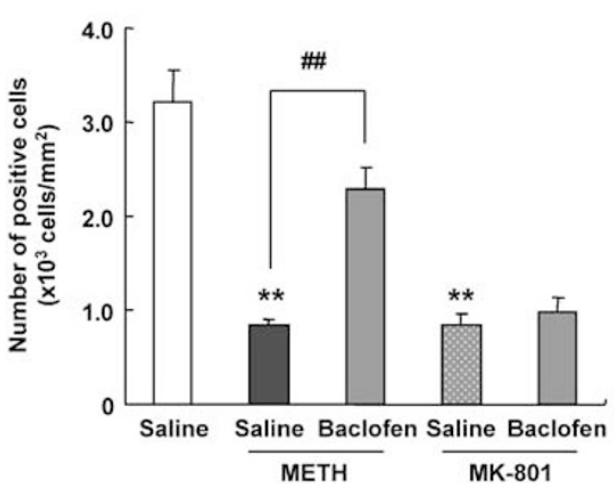

b

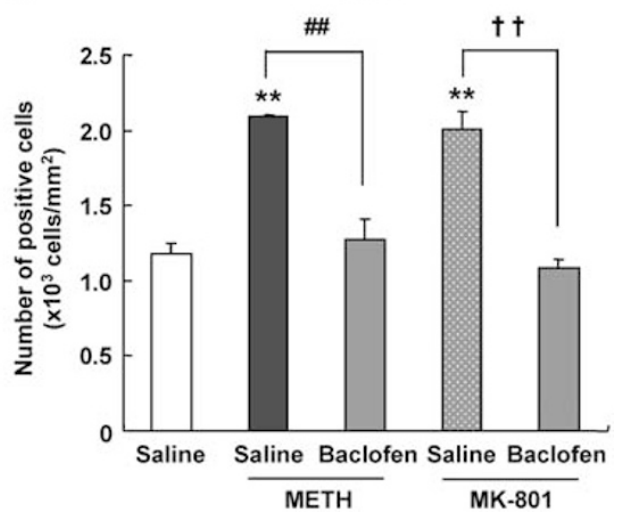

Figure 9 Effects of baclofen on METH- and MK-80I-induced changes in c-Fos expression in LGP (a) and PnC (b) after the PPI test. Mice were restricted to the PPI test cage, but not subjected to the PPI test (non-stimulated group). Alternatively, mice were subjected to the PPI test after pretreatment with saline, METH (3 mg/kg, s.c.), and MK-80 I (I mg/kg, s.c.), and baclofen ( $5 \mathrm{mg} / \mathrm{kg}$, s.c.) followed by METH or MK-80 I. Values indicate the mean \pm SE (a: saline, METH and MK-80 I, $n=3$, other groups, $n=4$; b: saline, METH and MK-80I, $n=3$, METH with baclofen, $n=4$, MK-80I with baclofen, $n=5$ ). $* * 2<0.00 \mathrm{I}$ vs the saline-treated control group. ${ }^{\# \#} p<0.00$ I vs. the METH-treated group. ${ }^{\dagger \dagger} p<0.00$ I vs the MK-80I-treated group (Bonnferroni/Dunn test).

\section{DISCUSSION}

The fast excitatory pathway of the acoustic startle system involves serial connections linking the auditory nerve, cochlear root neurons, PnC, and spinal motor neurons
(Lee et al, 1996). We have previously demonstrated that pulse stimulus increased c-Fos expression in the PnC, which was attenuated by a weak prepulse before pulse stimulus in the PPI test (Takahashi et al, 2007). Our findings are consistent with data indicating that $\mathrm{PnC}$ neurons are 
markedly inhibited by an acoustic prepulse in mice (Willot et al, 1994; Carlson and Willot, 1998). In this study, an increase in the number of c-Fos-positive cells in the PnC after the PPI test was evident only when PPI was disrupted by acute METH or MK- 801 treatment as well as repeated METH treatment. These results suggest that the fast excitatory pathway of the acoustic startle system, including $\mathrm{PnC}$, is activated even in the presence of prepulse stimulus if dopaminergic synaptic transmission is potentiated by METH or glutamatergic neurotransmission through NMDA receptors is blocked by MK-801, which results in the disruption of PPI of the acoustic startle reflex in mice.

We have also demonstrated that GABAergic neurons in LGP, which project directly to PPTg, are activated by prepulse stimulus regardless of startle pulse stimuli (Takahashi et al, 2007). Since the localized inactivation of LGP by lidocaine markedly reduced PPI without affecting the startle response induced by a pulse stimulus, it is suggested that GABAergic neurons in LGP play a crucial role in the regulation of PPI of the startle reflex. Moreover, we suggest that pallidotegmental GABAergic neurons act as an interface between the brainstem PPI-mediating areas and forebrain PPI-regulating areas (Takahashi et al, 2007). In this study, we demonstrated that PPI disruption induced by treatment with METH or MK-801 was accompanied by the dysfunction of LGP, which was manifested by a reduction of c-Fos expression in LGP after the PPI test. Although the causal relation between the phenomena is unclear, taking our previous findings into consideration, it is reasonable to assume that both METH and MK-801 disrupt PPI of the startle reflex in mice by inhibiting the activation of pallidotegmental GABAergic neurons evoked by a prepulse stimulus. Further studies are required to test this assumption. In particular, it remains to be determined how METH and MK-801 inhibited neural activation in LGP evoked by prepulse stimulus.

We have previously reported that repeated, but not acute, treatment with METH at a low dose $(1 \mathrm{mg} / \mathrm{kg})$ in mice induces long-lasting impairment of recognition memory, which is associated with dysfunction in the prefrontal cortex (Kamei et al, 2006). Because of the therapeutic effect of clozapine, but not haloperidol, on repeated METHinduced recognition memory impairment, we have proposed that this animal model may be useful for screening potential antipsychotics and studying the pathophysiology of cognitive deficits in schizophrenic patients as well as METH abusers. In patients suffering from schizophrenia and other psychiatric disorders, PPI is disrupted (Braff et al, 1978; Swerdlow et al, 1994, 1995; Castellanos et al, 1996). Accordingly, to further study the face validity of the animal model with repeated METH treatment, we measured the PPI of the acoustic startle reflex in mice that had previously been treated with METH $(1 \mathrm{mg} / \mathrm{kg}$ ) for 7 days. Mice with repeated METH treatment exhibited lasting impairment of PPI without any changes in startle amplitude, and PPI disruption was associated with the dysfunction of LGP and hyperactivation of PnC. These results are consistent with the clinical finding of whole-brain functional magnetic resonance imaging in groups of healthy subjects and schizophrenic patients: significant activation in the globus pallidus/putamen extending to the hippocampus and thalamus during the prepulse experiment was demonstrated in healthy subjects, but the patients showed a lack of activation in subcortical and limbic areas (Kumari et al, 2003).

We demonstrated in this study that baclofen, a $\mathrm{GABA}_{\mathrm{B}}$ receptor agonist, ameliorated both METH- and MK-801induced PPI impairment at doses that had no effect on PPI and the startle response by itself. Consistent with our findings, it was reported that baclofen reversed the reduction in PPI induced by MK-801, but not by apomorphine (a direct dopamine receptor agonist), in rats (Bortolato et al, 2004), and that baclofen and clozapine, but not haloperidol, improved spontaneous PPI deficit in mice (Bortolato et al, 2007). In addition, a recent study (Wolf et al, 2007) demonstrated that acute and subchronic treatment with clozapine failed to ameliorate PPI deficits in mice. Taken together, $\mathrm{GABA}_{\mathrm{B}}$ receptor agonists may be more useful for the treatment of schizophrenic patients and METH abusers with sensorimotor gating deficit than clozapine and other antipsychotic drugs.

The ameliorating effect of baclofen on PPI was associated with the normalization of $\mathrm{PnC}$ hyperactivation. These results are consistent with our previous finding that microinjection of a $\mathrm{GABA}_{B}$ receptor antagonist, phaclofen, but not a $\mathrm{GABA}_{\mathrm{A}}$ receptor antagonist, picrotoxin, into the PPTg impaired PPI in mice (Takahashi et al, 2007). Similarly, Koch et al (2000) indicated that microinjection of phaclofen, but not picrotoxin, into the PnC reduced PPI in rats, and that nigroreticular GABAergic projectioninteracting $\mathrm{GABA}_{\mathrm{B}}$ receptors are involved in sensorimotor gating.

Baclofen increased the number of c-Fos-positive cells in the LGP of METH-treated mice subjected to the PPI test, whereas it had no effect on MK-801-treated mice. Thus, it is possible that distinct but overlapping neural circuits may be involved in the ameliorating effect of baclofen on METHand MK-801-induced PPI deficits. For example, baclofen may ameliorate METH-induced PPI impairment, at least in part, through the activation of pallidotegmental GABAergic neurons, whereas it may improve MK-801-induced PPI impairment at PnC levels. Previous studies demonstrated that baclofen reduced the reinforcing effects of the main substances of abuse such as cocaine nicotine, heroine, and alcohol (Cousins et al, 2002), possibly through $\mathrm{GABA}_{\mathrm{B}^{-}}$ mediated modulation of mesolimbic dopamine transmission (Bartholini, 1985). In fact, baclofen is known to stabilize the firing pattern of dopamine neurons (Erhardt et al, 2002), and to block the development and expression of sensitization to the locomotor stimulation effect of amphetamine (Bartoletti et al, 2004, 2005). It is possible, therefore, that baclofen may ameliorate METH-induced PPI impairment by, at least in part, stabilizing the firing of dopamine neurons, which have been demonstrated to be of critical importance in the control of sensorimotor gating (Mansbach et al, 1988; Swerdlow and Geyer, 1998). It is clear that further studies are required to clarify the neurobiological mechanisms underlying the PPI deficit induced by METH and MK-801 as well as the restorative effect of baclofen on PPI disruption.

In conclusion, we demonstrated that PPI disruption caused by METH and MK-801 is associated with the dysfunction of pallidotegmental neurons in mice. Repeated METH-treated mice, an animal model for cognitive deficits 
in METH abuse and schizophrenia, exhibit PPI impairment. Furthermore, it was demonstrated that baclofen, a $\mathrm{GABA}_{\mathrm{B}}$ receptor agonist, is effective in ameliorating PPI disruptions caused by METH and MK-801, suggesting that $\mathrm{GABA}_{B}$ receptors may constitute a putative new target in treating neuropsychiatric disorders with sensorimotor gating deficits, such as schizophrenia and METH psychosis.

\section{ACKNOWLEDGEMENTS}

This study was supported in part by a Grant-in-Aid for Scientific Research (19390062) and for the 21st Century COE Program from the Ministry of Education, Culture, Sports, Science and Technology of Japan, a grant from the Smoking Research Foundation, and JSPS and KOSEF under the Japan-Korea Basic Scientific Cooperation Program.

\section{DISCLOSURE/CONFLICT OF INTEREST}

There are no conflicts of interest.

\section{REFERENCES}

Bartholini G (1985). GABA receptor agonists: pharmacological spectrum and therapeutic action. Med Res Rev 5: 55-75.

Bartoletti M, Gubellini C, Ricci F, Gaiardi M (2004). The GABAB agonist baclofen blocks the expression of sensitization to the locomotor stimulant effect of amphetamine. Behav Pharmacol 15: $397-401$.

Bartoletti M, Gubellini C, Ricci F, Gaiardi M (2005). Baclofen blocks the development of sensitization to the locomotor stimulant effect of amphetamine. Behav Pharmacol 16: 553-558.

Benes FM, Berretta S (2001). GABAergic interneurons: implications for understanding schizophrenia and bipolar disorder. Neuropsychopharmacology 25: 1-27.

Benes FM, Vincent SL, Marie A, Khan Y (1996). Up-regulation of $\mathrm{GABA}_{\mathrm{A}}$ receptor binding on neurons of the prefrontal cortex in schizophrenic subjects. Neuroscience 75: 1021-1031.

Bortolato M, Frau R, Aru GN, Orrù M, Gessa GL (2004). Baclofen reverses the reduction in prepulse inhibition of the acoustic startle response induced by dizocilpine, but not by apomorphine. Psychopharmacology (Berl) 171: 322-330.

Bortolato M, Frau R, Orrù M, Piras AP, Fà M, Tuveri A et al (2007). Activation of $\mathrm{GABA}(\mathrm{B})$ receptors reverses spontaneous gating deficits in juvenile DBA/2J mice. Psychopharmacology 194: 361-369.

Braff D, Grillon C, Gallaway E, Geyer M, Bali L (1978). Prestimulus effects on human startle reflex in normals and schizophrenics. Psychophysiology 15: 339-343.

Braff DL, Geyer MA (1990). Sensorimotor gating and schizophrenia: human and animal model studies. Arch Gen Psychiatry 47: 181-188.

Carlson S, Willot JF (1998). Caudal pontine reticular formation of C57BL/6J mice: response to startle stimuli, inhibition by tones and plasticity. J Neurophysiol 79: 2603-2614.

Castellanos FX, Fine EJ, Kaysen DL, Kozuch PL, Hamburger SD, Rapoport JL et al (1996). Sensorimotor gating in boys with Tourette's syndrome and ADHD. Biol Psychiatry 39: 33-41.

Cousins MS, Roberts DC, De Wit H (2002). $\mathrm{GABA}_{B}$ receptor agonists for the treatment of drug addiction: a review of recent findings. Drug Alcohol Depend 65: 209-220.

Curzon P, Decker MW (1998). Effects of phencyclidine (PCP) and $(+)$ MK-801 on sensorimotor gating in CD-1 mice. Prog Neuropsychopharmacol Biol Psychiatry 22: 129-146.
Dai H, Okuda H, Iwabuchi K, Sakurai E, Chen Z, Kato M et al (2004). Social isolation stress significantly enhanced the disruption of prepulse inhibition in mice repeatedly treated with methamphetamine. Ann NY Acad Sci 1025: 257-266.

Ellenbroek BA, Lubbers LJ, Cools AR (2002). The role of hippocampal dopamine receptors in prepulse inhibition. Eur J Neurosci 15: 1237-1243.

Erhardt S, Mathe JM, Chergui K, Engberg G, Svensson TH (2002). $\mathrm{GABA}_{\mathrm{B}}$ receptor-mediated modulation of the firing pattern of ventral tegmental area dopamine neurons in vivo. Naunyn Schmiedebergs Arch Pharmacol 365: 173-180.

Fendt M, Li L, Yeomans JS (2001). Brain stem circuits mediating prepulse inhibition of the startle reflex. Psychopharmacol (Berl) 156: $216-224$.

Franklin KBJ, Paxinos G (1997). The Mouse Brain in Stereotaxic Coordinates. Academic Press: NY.

Herdegen T, Leah JD (1998). Inducible and constitutive transcription factors in the mammalian nervous system: control of gene expression by Jun, Fos and Krox, and CREB/ATF proteins. Brain Res Rev 28: 370-490.

Hoffman HS, Ison JR (1980). Reflex modification in the domain of startle: I. Some empirical findings and their implications for how the nervous system processes sensory input. Psychol Rev 87: 175-189.

Ishikawa M, Mizukami K, Iwakiri M, Asada T (2005). Immunohistochemical and immunoblot analysis of gammaaminobutyric acid B receptor in the prefrontal cortex of subjects with schizophrenia and bipolar disorder. Neurosci Lett 383: 373-377.

Ison JR, Hammond GR (1971). Modification of the startle reflex in the rat by changes in the auditory and visual environments. J Comp Physiol Psychol 75: 435-452.

Kamei H, Nagai T, Nakano H, Togan Y, Takayanagi M, Takahashi K et al (2006). Repeated methamphetamine treatment impairs recognition memory through a failure of novelty-induced ERK1/2 activation in the prefrontal cortex of mice. Biol Psychiatry 59: 75-84.

Koch M, Fendt M, Kretschmer BD (2000). Role of the substantia nigra pars reticulata in sensorimotor gating, measured by prepulse inhibition of startle in rats. Behav Brain Res 117: 153-162.

Kumari V, Gray JA, Geyer MA, ffytche D, Soni W, Mitterschiffthaler MT et al (2003). Neural correlates of tactile prepulse inhibition: a functional MRI study in normal and schizophrenic subjects. Psychiatry Res 122: 99-113.

Lee Y, Lopez DE, Meloni EG, Davis M (1996). A primary acoustic startle pathway: obligatory role of cochlear root neurons and the nucleus reticularis pontis caudalis. J Neurosci 16: 3775-3789.

Lewis DA, Cruz DA, Melchitzky DS, Pierri JN (2001). Laminaspecific deficits in parvalbumin-immunoreactive varicosities in the prefrontal cortex of subjects with schizophrenia: evidence for fewer projections from the thalamus. Am J Psychiatry 158: $1411-1422$.

Mansbach RS, Geyer MA, Braff DL (1988). Dopaminergic stimulation disrupts sensorimotor gating in the rat. Psychopharmacology (Berl) 94: 507-514.

Mizukami K, Sasaki M, Ishikawa M, Iwakiri M, Hidaka S, Shiraishi H et al (2000). Immunohistochemical localization of gammaaminobutyric acid (B) receptor in the hippocampus of subjects with schizophrenia. Neurosci Lett 283: 101-104.

Swerdlow NR, Braff DL, Taaid N, Geyer MA (1994). Assessing the validity of an animal model of deficient sensorimotor gating in schizophrenic patients. Arch Gen Psychiat 51: 139-154.

Swerdlow NR, Geyer MA (1998). Using an animal model of deficient sensorimotor gating to study the pathophysiology and new treatments of schizophrenia. Schizophr Bull 24: 285-301.

Swerdlow NR, Geyer MA, Braff DL (2001). Neural circuit regulation of prepulse inhibition of startle in the rat: current 
knowledge and future challenges. Psychopharmacology 156: 194-215.

Swerdlow NR, Paulsen J, Braff DL, Butters N, Geyer MA, Swenson MR (1995). Impaired prepulse inhibition of the acoustic and tactile startle response in patients with Huntington's disease. J Neurol Neurosurg Psychiatry 58: 192-200.

Takahashi K, Nagai T, Kamei H, Maeda K, Matsuya T, Arai S et al (2007). Neural circuits containing pallidotegmental GABAergic neurons are involved in the prepulse inhibition of the startle reflex in mice. Biol Psychiatry 62: 148-157.
Yeomans JS, Lee J, Yeomans MH, Steidl S, Li L (2006). Midbrain pathways for prepulse inhibition and startle activation in rat. Neuroscience 142: 921-929.

Willot JF, Carlson C, Chen H (1994). Prepulse inhibition of the startle response in mice: relationship to hearing loss and auditory system plasticity. J Neuphysiol 79: 2603-2614.

Wolf R, Paelchen K, Matzke K, Dobrowolny H (2007). Acute or subchronic clozapine treatment does not ameliorate prepulse inhibition (PPI) deficits in CPB-K mice with low levels of hippocampal NMDA receptor density. Psychopharmacology (Berl) 194: 93-102.

Supplementary Information accompanies the paper on the Neuropsychopharmacology website (http://www.nature.com/npp) 